\title{
Distribution and production of plankton communities in the subtropical convergence zone of the Sargasso Sea. I. Phytoplankton and bacterioplankton
}

\author{
Lasse Riemann ${ }^{1,7, *}$, Torkel Gissel Nielsen ${ }^{2,6}$, Theis Kragh $^{3}$, Katherine Richardson ${ }^{4}$, \\ Hjalte Parner ${ }^{5}$, Hans Henrik Jakobsen ${ }^{6,2}$, Peter Munk ${ }^{6}$ \\ ${ }^{1}$ Department of Natural Sciences, Linnaeus University, 39182 Kalmar, Sweden \\ ${ }^{2}$ National Environmental Research Institute, Aarhus University, Department of Marine Ecology, 4000 Roskilde, Denmark \\ ${ }^{3}$ Freshwater Biological Laboratory, University of Copenhagen, Helsingørsgade 51, 3400 Hillerød, Denmark \\ ${ }^{4}$ University of Copenhagen, Center for Macroecology, Evolution and Climate, 2200 Copenhagen N, Denmark \\ ${ }^{5}$ International Council for the Exploration of the Sea (ICES), 1553 Copenhagen V, Denmark \\ ${ }^{6}$ National Institute of Aquatic Resources, DTU Aqua Section for Oceanecology and Climate, \\ Technical University of Denmark, DTU Kavalergården 6, 2920 Charlottenlund, Denmark \\ ${ }^{7}$ Marine Biological Section, University of Copenhagen, Strandpromenaden 5, 3000 Helsingør, Denmark
}

\begin{abstract}
Elevated levels of biomass and productivity are often associated with ocean frontal systems. The Subtropical Convergence Zone (STCZ) in the southern Sargasso Sea shows pronounced and stable thermal fronts, but little is known about the ecological consequences of these hydrographic features. With the aim of improving the understanding of physical and lower trophic level processes in the area, we carried out field studies of physical, chemical and biological characteristics along 3 transects crossing thermal fronts associated with the STCZ in March to April 2007. Thermal and chemical stratification were evident at all stations within the STCZ, and a depletion of nitrate was measured in the upper $\sim 150 \mathrm{~m}$. The phytoplankton biomass was dominated by Prochlorococcus spp. with highest abundance, up to $>400000$ cells ml$^{-1}$, at the chlorophyll a (chl a) maximum at 100 to $150 \mathrm{~m}$ depth. Synechococcus spp. were generally located higher in the water column. Picoalgae were less abundant, up

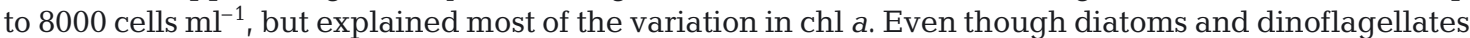
were few, the biomass of larger phytoplankton equalled or exceeded that of picoplankton at a few stations. Bacterial biomass was roughly equal to half of the phytoplankton biomass. We did not find elevated levels of primary production or biomass of specific phytoplankton groups associated with the STCZ, probably due to a pronounced variability between stations along transects. Nevertheless, distinct increases in chl a were associated with the zone and thermal fronts bordering the STCZ.
\end{abstract}

KEY WORDS: Sargasso Sea $\cdot$ Picoalgae $\cdot$ Bacteria $\cdot$ Prochlorococcus $\cdot$ Synechococcus $\cdot$ Convergence zone

\section{INTRODUCTION}

Oligotrophic conditions characterise more than $75 \%$ of the surface waters of the world's oceans. Considering the extent of such oligotrophic waters, knowledge about their dynamics is limited. Extensive information about the function and characteristics of oligotrophic oceans is available from the US Joint Global Ocean
Flux Study (JGOFS) time series stations near Hawaii and Bermuda. Long-term sampling at the Bermuda Atlantic Time-series Study (BATS) site has provided valuable insights into the seasonal chemical and biological oceanography of the north-western Sargasso Sea off Bermuda (reviewed by Steinberg et al. 2001). These data and data from other Sargasso regions (e.g. Olson et al. 1990, Siegel et al. 1990) indicate a 
large temporal and spatial variation in plankton composition, biomass and productivity; hence, conclusions drawn from restricted sampling sites, such as BATS, are not likely to be valid for other parts of the Sargasso Sea.

The Sargasso Sea is the centre of the North Atlantic subtropical gyre bordered by the Gulf Stream to the north and west, by the North Equatorial Current to the south and by regions of weak recirculation flow to the east (Siegel et al. 1990). The Subtropical Convergence Zone (STCZ) meandering from 22 to $32^{\circ} \mathrm{N}$ is a characteristic feature of the Sargasso Sea in which cold waters from the north and warm tropical waters from the south meet and generate a complex pattern of fronts and eddies (Voorhis \& Hershey 1964, Halliwell et al. 1994). Vertically, nutrient-rich $18^{\circ} \mathrm{C}$ water is found beneath the main thermocline (Wegner 1982). Many studies have focussed on biomass, activity or seasonal dynamics of various trophic levels in the pelagic food web in the Sargasso Sea. However, with only few exceptions (e.g. Böttger 1982, Olson et al. 1990, Siegel et al. 1990), these studies have reported from areas located north of the STCZ, e.g. BATS (Lohrenz et al. 1992, Roman et al. 1993, Carlson et al. 1994) or other stations ( $\mathrm{Li}$ et al. 1992, Goericke \& Welschmeyer 1993). Hence, information on the interaction between the frontal oceanography and horizontal and vertical variability in food web dynamics across the STCZ is sparse.

Differences in water column stability will influence the nutrient supply to the euphotic zone. In general, well-mixed nutrient-rich oceans support classical food chains with large phytoplankton and copepods, whereas oligotrophic stratified waters are dominated by small phytoplankton and relatively high heterotrophic biomasses (Gasol et al. 1997). How these scenarios apply to oceanic frontal systems is unknown; however, a few studies indicate that the fronts stimulate productivity. For instance, fluorescence and abundance of copepods were highest near frontal features in the Japan/East Sea (Ashjian et al. 2005), and phytoplankton growth rates were near maximal in the subtropical convergence off New Zealand, but decreased to less than half of the maximal north and south of that front (Delizo et al. 2007). In the present study, we hypothesised that the convergence of different water masses in the STCZ causes an elevated level of biological biomass and activity. We describe the lower trophic levels (primary producers and bacteria) of the planktonic food web in combination with data on physical and chemical oceanography from 3 parallel south-north transects across the STCZ. Additional quantification of higher zooplankton distributions, production and the overall food web structure in the different regions of the STCZ are treated in the companion paper (Andersen et al. 2011, this volume).

\section{MATERIALS AND METHODS}

Sampling was carried out from the Danish Navy surveillance frigate RV 'Vaedderen' during the Danish 'Galathea 3' expedition in the period 29 March to 10 April 2007, leg 17. Samples were obtained from 33 stations positioned along 3 north-south transects (Fig. 1). Additional data on currents and the frontal hydrography of the sampled STCZ region have been presented elsewhere (Munk et al. 2010).

Sea surface temperature. High-resolution satellite sea surface temperature (SST) observations (Fig. 1) were obtained from the GODAE High Resolution SST pilot project (http://ghrsst-pp.org) including data from the satellites ENVISAT (1 km resolution), NOAA 17 and 18 (2 and $9 \mathrm{~km}$ resolution), MODIS Aqua $(1 \mathrm{~km}$ resolution) and AMSR-E (25 km resolution). The observations were merged into a $0.05^{\circ}$ by $0.05^{\circ}$ spatial grid using optimal interpolation that accounts for the statistical properties of the observations and individual noise and bias levels (Høyer \& She 2007). To avoid the influence of diurnal variations, only night-time data were used.

Water column structure and sampling. Vertical profiles of salinity and temperature were measured to 400 m depth using a Seabird 9/11 CTD equipped with a 12 Niskin bottle (30 l) rosette sampler. In addition, the CTD was equipped with a SCUFA Turner design fluorometer and PAR-light recorders (Biospherical Instruments, deck unit QSP-2200 and underwater unit QSP-2300). Water samples of chemical and biological parameters were obtained from 10, 60, 100, fluorescence maximum, 200 and $400 \mathrm{~m}$ at all stations. At Stn 23, a deeper cast down to $4000 \mathrm{~m}$ was also made. A number of different projects were being carried out on the ship simultaneously. Therefore, it was not possible to specify specific times for sampling. Chlorophyll a (chl a), nutrients and phytoplankton abundances were measured at all 33 stations, while bacterial and primary production were measured at 16 and 10 stations, respectively (Fig. 1, see Table 2). Biomasses and productions were trapezoidally integrated to 150 or $400 \mathrm{~m}$, at which depth the concentrations were set to 0 . Vertical profiles were contoured using the program Surfer (Golden Software). Data were interpolated into a regular grid using inverse distances to the power of 2, and subsequently lines were contoured between these using a spline function.

Chl $\boldsymbol{a}$ and nutrients. Samples $(33 \mathrm{ml})$ for nutrient analyses were taken directly from the Niskin bottles and immediately frozen. Nutrient concentrations were later determined using an automatic nutrient analyser (Dansk Havteknik; Grasshoff et al. 1983) with detection limits of $0.06,0.1,0.04,0.3$ and $0.2 \mu \mathrm{M}$ for phosphorus, nitrate, nitrite, ammonia and silicate, respec- 


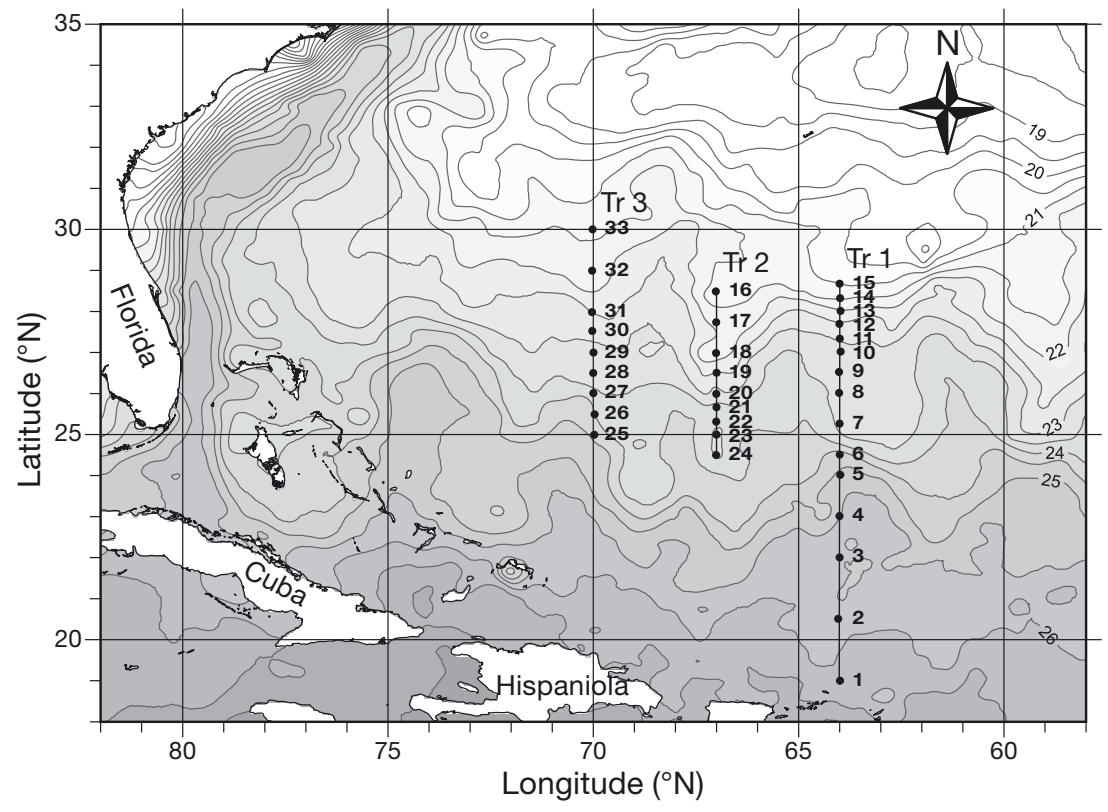
isolines as determined from satellite images, stations $(\bullet)$ numbered from 1 to 33
Fig. 1. Sargasso Sea. Tr 1,2,3=3 sampled transects relative to temperature $\left({ }^{\circ} \mathrm{C}\right)$

served with filter-sterilised glutaraldehyde ( $2 \%$ final concentration), stored at $4^{\circ} \mathrm{C}$, and analysed within 1 to $2 \mathrm{~d}$. Bacterial abundance was determined by flow cytometry (FACS Calibur, Becton Dickinson) after staining the fixed cells with SYBR Green I (Molecular Probes; Marie et al. 1997). Twenty random samples were counted by microscopy after staining with SYBR Green I ( $\geq 12$ fields or 200 cells). Microscopy counts and flow cytometric estimates correlated closely in a Model II regression with a slope of $1.03 \pm 0.08\left(\mathrm{r}^{2}=\right.$ $0.97, \mathrm{n}=20$ and $\mathrm{p}<0.05)$. The flow rate of samples through the FACS Calibur was determined using BD Biosciences TruecountTM tubes. Picophytoplankton were fixed and counted as for bacteria but without staining. Gating of Prochlorococcus and Synechococcus, and picophytoplankton was defined using cultures of Prochlorococcus, tively. Chl $a$ and phaeopigments (total and $>10 \mu \mathrm{m}$ ) were measured on 500 and $1000 \mathrm{ml}$ triplicate samples from $10 \mathrm{~m}$, the fluorescence maximum and $200 \mathrm{~m}$, filtered onto Whatmann GF/F and $10 \mu \mathrm{m}$ nitex filters, respectively. The filters were extracted overnight in ethanol (Jespersen \& Christoffersen 1987) and measured before and after acid addition (3 drops of $1 \mathrm{~N}$ $\mathrm{HCl}$ ) on a Turner Designs Model 700 fluorometer calibrated with a pure chl a standard. Depth profiles of chl a were obtained by converting CTD fluorescence profiles to chl a using the relationship between fluores-

Abundance and biomass of larger phytoplankton. Samples (300 ml) collected from $10 \mathrm{~m}$ depth and from the fluorescence maximum were fixed in acid Lugol's solution ( $2 \%$ final concentration), stored in the dark at $5^{\circ} \mathrm{C}$ and analysed using inverted microscopy within 3 mo. Phytoplankton settled for $24 \mathrm{~h}$ in $50 \mathrm{ml}$ Uthermöhl chambers prior to microscopy. Phytoplankton cells, defined as flagellates $>4 \mu \mathrm{m}$ or identified by eye, were divided into taxon groups, and enumerated and sized in $10 \mu \mathrm{m}$ intervals. Volumes of taxon groups were determined using appropriate morphology-derived volume relationships. Cellular carbon content was estimated from a generic protist specific volume: carbon regression (Menden-Deuer \& Lessard 2000).

Abundance of bacteria and picophytoplankton. Samples of $4 \mathrm{ml}$ were precence and measured chl a $\left(\mathrm{r}^{2}=0.86, \mathrm{n}=86\right)$.
Synechococcus and picophytoplankton (Phaeocystis spp., Rhodomonas spp., Emiliana huxleyi, Pycnococcus spp., Pelagococcus subviridis, Pelagococcus spp.), and was verified onboard by comparison with microscopy counts. Sizes of Prochlorococcus, Synechococcus and eukaryotic picophytoplankton (here referred to as picoalgae) were estimated in all samples from forward scatter and calibrated against 8 cultures of Prochlorococcus, Synechococcus and eukaryotic picophytoplankton (Micromonas pusilla strains K-0024 and K-0023, Nannochloropsis oculata, Thalassiosira pseudonana) varying in cellular diameter from 0.6 to 3.1 $\mu \mathrm{m}$. Average cell sizes from respective depths (Table 1) were multiplied with cell concentrations and then con-

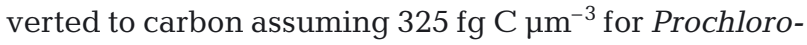
coccus and Synechococcus (DuRand et al. 2001). The biovolume of picoalgae was converted to carbon per
Table 1. Picophytoplankton. Diameters as determined from forward scatter using flow cytometry (values $\pm 95 \%$ CI). Samples with $<20$ gated events were excluded from the analysis. Chl a max: chlorophyll a maximum (depths varied between 110 and $165 \mathrm{~m}), \mathrm{n}=$ number of stations

\begin{tabular}{|lcccccc|}
\hline \multirow{2}{*}{$\begin{array}{l}\text { Depth } \\
(\mathrm{m})\end{array}$} & Picoalgae & $\mathrm{n}$ & Prochlorococcus & $\mathrm{n}$ & Synechococcus & $\mathrm{n}$ \\
\cline { 5 - 7 } & $2.27 \pm 0.15$ & 27 & $0.52 \pm 0.03$ & 31 & $0.86 \pm 0.06$ & 32 \\
10 & $1.89 \pm 0.12$ & 29 & $0.63 \pm 0.04$ & 30 & $0.82 \pm 0.05$ & 30 \\
60 & $1.33 \pm 0.09$ & 31 & $0.65 \pm 0.04$ & 31 & $0.84 \pm 0.06$ & 33 \\
100 & $1.02 \pm 0.07$ & 29 & $0.65 \pm 0.04$ & 32 & $0.94 \pm 0.06$ & 33 \\
Chl a max. & $1.02 \pm 0.07$ & 25 & $0.57 \pm 0.04$ & 31 & $0.98 \pm 0.06$ & 31 \\
200 & $1.04 \pm 0.07$ & 5 & $0.65 \pm 0.05$ & 17 & $0.97 \pm 0.06$ & 29 \\
400 & & & & & & \\
\hline
\end{tabular}


cell using the empirical relationship log $\left(\mathrm{pg}\right.$ cell $\left.^{-1}\right)=$ $0.94 \log \mathrm{Vol}\left(\mu^{3}\right)-0.6$ (Eppley et al. 1970), and then multiplied by cell concentration.

Primary production. Photosynthetic activity was determined daily at the water collection station closest to 09:00 h local time. Water samples were taken from 2 depths: $10 \mathrm{~m}$ and from the subsurface chlorophyll peak (varying depth depending on station characteristics). The photosynthetic characteristics from the deep sample were assumed to represent photosynthetic activity below the surface mixed layer, while the $10 \mathrm{~m}$ sample was assumed to be representative for the surface mixed layer. The photosynthetic characteristics obtained at each depth were normalised to chl a concentration at the sampling depth. The depth of the surface mixed layer was determined from the CTD cast. The primary production was measured according to a modified carbon-14 method (Steemann Nielsen 1952). Both particulate (i.e. retained on a Whatman GF/F filter) and total primary production (i.e. the ${ }^{14} \mathrm{C}$ retained in the incubation water after acidification of the sample to remove non-incorporated ${ }^{14} \mathrm{CO}_{2}$ ) were determined. Primary production versus light intensity curves were fitted to the data which were generated in incubations carried out in $50 \mathrm{ml}$ polyethylene bottles for $2 \mathrm{~h}$ at 12 different light intensities (1 bottle at each light intensity) ranging from $<10$ to $>1000 \mu \mathrm{mol} \mathrm{m}{ }^{-2} \mathrm{~s}^{-1}$ and 2 dark bottles from each sampling depth. The dark bottles were subtracted from the light incubation samples. Primary production was calculated by creating a matrix of potential production through the water column over the light period of the day using the established primary production versus light intensity curves and the light climate at meter intervals through the water column throughout the day (estimated from the measured attenuation coefficient and 'incident' light during the week of sampling, i.e. hourly averages made over a $7 \mathrm{~d}$ average around the date of the sampling). By using these weekly averages of incident light, the potential primary production at stations sampled on days with different light conditions could be compared. No correction was made for possible isotope discrimination or photo-inhibition occurring in the water column. We acknowledge that photo-inhibition might be predicted to occur in surface waters of the Sargasso Sea. However, it is unclear to what extent incubations at constant light intensities replicate in situ conditions. We became concerned about using the photosynthesis model of Platt et al. (1980), in which photo-inhibition was included, after we made a comparison of water column primary production calculated using our model and calculated using the model of Platt et al. (1980) on data we collected on the entire Galathea 3 Expedition, which visited all major ocean basins (data not shown). A strong linear relationship
$\left(\mathrm{R}^{2}=0.95, \mathrm{n}=82\right)$ was revealed between the results obtained with the 2 models, where results using Platt et al.'s (1980) photo-inhibition model were $27 \%$ lower than in our model, which does not include photo-inhibition. We cannot explain why the effect of applying the photo-inhibition parameter in the model of Platt et al. (1980) should yield a more or less constant reduction in water column photosynthesis at high and low productive stations and under varying ambient light conditions. We therefore chose not to include photoinhibition in our model. The euphotic zone was assigned as being the waters above the depth of the penetration of $0.1 \%$ surface irradiance $(\sim 150 \mathrm{~m}$ at the stations sampled here), and the dissolved inorganic carbon content was measured on seawater samples (fixed with $\mathrm{HgCl}_{2}$ ) by coulometric titration using a UIC model $5012 \mathrm{CO}_{2}$ coulometer.

Bacterial production. Bacterial production was measured by dual incorporation of $\left[{ }^{14} \mathrm{C}\right]$-leucine $(10 \mathrm{nM}$ final; Kirchman et al. 1985) and $\left[{ }^{3} \mathrm{H}\right]$-thymidine (10 nM final; Fuhrman \& Azam 1982). Triplicate $10 \mathrm{ml}$ samples with isotopes were incubated at in situ temperature $\pm 2^{\circ} \mathrm{C}$ for $\sim 2 \mathrm{~h}$. Incubations were stopped by the addition of trichloroacetic acid (5\% final), and samples were filtered onto $0.2 \mu \mathrm{m}$ mixed cellulose ester filters (Advantec). Samples with 5\% trichloroacetic acid added prior to the addition of isotopes served as blanks. Leucine and thymidine incorporation were converted

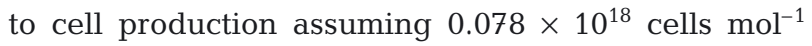
leucine and $1.63 \times 10^{18}$ cells mol $^{-1}$ thymidine as determined for the Sargasso Sea (Carlson et al. 1996). A carbon:cell ratio of $10 \mathrm{fg} \mathrm{C}^{\mathrm{C}} \mathrm{cell}^{-1}$ (Ducklow 2000) was used. Bacterial carbon production was calculated from leucine incorporation, while cell specific growth rates were calculated from thymidine incorporation and bacterial abundance assuming exponential growth. Incorporation of thymidine and leucine was highly correlated $\left(\mathrm{r}^{2}=0.71, \mathrm{n}=108\right)$.

Statistics. Statistical analyses were conducted in GraphPad Prism 5. Correlations were determined with Pearson's correlation analyses while pairwise comparisons were carried out using a paired $t$-test. Parameters are described as significantly different when the significance level of $\leq 0.05$ was met.

\section{RESULTS}

This study focused on the oceanography and the plankton in the upper $400 \mathrm{~m}$ of the water column. A comparison with data from a deep cast (Stn 23) showed that the upper $400 \mathrm{~m}$ contained $>99 \%$ of the photosynthesising organisms and more than half of the bacterial biomass and production compared to the values integrated down to $4000 \mathrm{~m}$ depth (data not shown). 


\section{Physical and chemical oceanography}

Along the 3 transects, the surface temperatures differed markedly between specific areas (Fig. 1). This is especially marked on Transect 1 , where 2 sharp gradients and a mixed zone in-between are apparent. We identify this feature as the STCZ (Fig. 1, Table 2). In vertical sections, most apparent along Transect 1 , the zone is evident as a lifting of the thermocline extending from $\sim 100$ to $200 \mathrm{~m}$ depth (Fig. 2a). The temperature range across the thermocline and frontal zone was from $\sim 20$ to $24.5^{\circ} \mathrm{C}$ (Fig. $2 \mathrm{a}-\mathrm{C}$ ).

Surface temperature extremes were $\sim 26$ and $\sim 19^{\circ} \mathrm{C}$ at the southern- and northernmost stations, respec- tively (Fig. 2a-c). Salinity ranged from 36.11 to 37.12 . An intrusion of warm $\left(\sim 26^{\circ} \mathrm{C}\right)$, low-saline $(\sim 36)$ and low-density water was measured in the upper $\sim 75 \mathrm{~m}$ in the southern part of Transect 1, marking the southern edge of the STCZ. Except for the northernmost stations, stratification was evident at all stations. On all transects, we observed depletion of nitrate in the upper $\sim 150 \mathrm{~m}$, with the exception of the northernmost stations of Transect 1 (up to $\sim 0.7 \mu \mathrm{mol} \mathrm{l}^{-1}$ nitrate; Fig. $2 \mathrm{~d}-\mathrm{f}$ ). Nitrate concentrations increased with depth below $150 \mathrm{~m}$ to $3.5-10.0 \mu \mathrm{mol}^{-1}$ at $400 \mathrm{~m}$ (Fig. $2 \mathrm{~d}-\mathrm{f}$ ). Phosphate and silicate also increased with depth, but these nutrients were also found at concentrations above detection level in the surface layer $(0-200 \mathrm{~m})$ of

Table 2. Integrated biomass and production of bacterioplankton and primary producers along 3 transects in the Sargasso Sea $(0$ to $400 \mathrm{~m}$ depth). Grey areas indicate the Subtropical Convergence Zone (STCZ). Stations are arranged from north (top) to south (bottom) for each transect. Larger algae include diatoms, chlorophyll-containing flagellates $(>4 \mu \mathrm{m})$ and dinoflagellates. Biomass ratio $=$ bacteria:primary producers. Fraction = fraction of primary production processed by bacteria, assuming a bacterial growth efficiency of 0.14 (Carlson \& Ducklow 1996)

\begin{tabular}{|c|c|c|c|c|c|c|c|c|c|c|c|c|}
\hline \multirow[t]{2}{*}{$\begin{array}{l}\text { Station } \\
\text { no. }\end{array}$} & \multirow[t]{2}{*}{$\begin{array}{l}\text { Latitude } \\
\left({ }^{\circ} \mathrm{N}\right)\end{array}$} & \multirow[t]{2}{*}{$\begin{array}{l}\text { Longitude } \\
\qquad\left({ }^{\circ} \mathrm{W}\right)\end{array}$} & \multicolumn{5}{|c|}{$\begin{array}{c}\text { Dominant phytoplankton groups }- \\
\text { Biomass }\left(\mathrm{mg} \mathrm{C} \mathrm{m}^{-2}\right)\end{array}$} & \multirow{2}{*}{$\begin{array}{c}\text { Primary } \\
\text { production } \\
\left(\mathrm{mg} \mathrm{C}^{-2} \mathrm{~d}^{-1}\right)\end{array}$} & \multirow{2}{*}{$\begin{array}{c}\text { Bacterial } \\
\text { biomass } \\
\left(\mathrm{mg} \mathrm{C} \mathrm{m}^{-2}\right)\end{array}$} & \multirow{2}{*}{$\begin{array}{c}\text { Bacterial } \\
\text { production } \\
\left(\mathrm{mg} \mathrm{C}^{-2} \mathrm{~d}^{-1}\right)\end{array}$} & \multirow{2}{*}{$\begin{array}{c}\text { Biomass } \\
\text { ratio }\end{array}$} & \multirow[t]{2}{*}{$\begin{array}{c}\text { Fraction } \\
(\%)\end{array}$} \\
\hline & & & $\begin{array}{l}\text { Prochloro- } \\
\text { coccus }\end{array}$ & $\begin{array}{l}\text { Synecho- } \\
\text { coccus }\end{array}$ & $\begin{array}{l}\text { Pico- } \\
\text { algae }\end{array}$ & Sum & $\begin{array}{l}\text { Larger } \\
\text { algae }\end{array}$ & & & & & \\
\hline \multicolumn{13}{|c|}{ Transect 1} \\
\hline 15 & 28.66 & 64.00 & 738 & 393 & 81 & 1212 & 1424 & & 752 & & 0.3 & \\
\hline 14 & 28.33 & 64.00 & 854 & 476 & 90 & 1420 & 426 & & 848 & 44 & 0.5 & \\
\hline 13 & 28.00 & 64.00 & 608 & 395 & 116 & 1119 & 1535 & & 809 & & 0.3 & \\
\hline 12 & 27.66 & 64.00 & 1014 & 221 & 289 & 1524 & 1222 & 483 & 932 & & 0.3 & \\
\hline 11 & 27.33 & 64.00 & 940 & 190 & 144 & 1274 & 1010 & & 855 & 44 & 0.4 & \\
\hline 10 & 27.00 & 64.00 & 842 & 181 & 165 & 1188 & 619 & & 957 & & 0.5 & \\
\hline 9 & 26.50 & 64.00 & 607 & 312 & 226 & 1145 & 1100 & 419 & 948 & 35 & 0.4 & 60 \\
\hline 8 & 26.00 & 64.00 & 746 & 196 & 165 & 1107 & 992 & & 973 & & 0.5 & \\
\hline 7 & 25.25 & 64.00 & 1034 & 334 & 125 & 1493 & 746 & 127 & 971 & 51 & 0.4 & 289 \\
\hline 6 & 24.50 & 64.00 & 728 & 67 & 44 & 839 & 804 & & 778 & & 0.5 & \\
\hline 5 & 24.00 & 64.00 & 642 & 137 & 100 & 879 & & & 903 & 61 & 1.0 & \\
\hline 4 & 23.00 & 64.00 & 882 & 118 & 135 & 1135 & 761 & & 1199 & & 0.6 & \\
\hline 3 & 22.04 & 64.00 & 1379 & 157 & 188 & 1724 & 960 & 310 & 1369 & 78 & 0.5 & 179 \\
\hline 2 & 20.50 & 64.01 & 892 & 88 & 69 & 1049 & 414 & & 1133 & & 0.8 & \\
\hline 1 & 19.00 & 64.00 & 1009 & 127 & 152 & 1288 & 1541 & 396 & 1253 & 55 & 0.4 & 99 \\
\hline \multicolumn{13}{|c|}{ Transect 2} \\
\hline 16 & 28.50 & 67.00 & 973 & 470 & 227 & 1670 & 627 & 358 & 1207 & 74 & 0.5 & 147 \\
\hline 17 & 27.75 & 67.00 & 737 & 309 & 180 & 1226 & 956 & & 845 & & 0.4 & \\
\hline 18 & 27.00 & 67.00 & 1036 & 447 & 162 & 1645 & 976 & & 979 & & 0.4 & \\
\hline 19 & 26.50 & 67.00 & 1262 & 636 & 281 & 2179 & 562 & 118 & 1022 & 65 & 0.4 & 394 \\
\hline 20 & 26.00 & 67.00 & 1337 & 408 & 235 & 1980 & 827 & & 1025 & & 0.4 & \\
\hline 21 & 25.66 & 67.00 & 565 & 165 & 42 & 772 & 1324 & & 745 & 58 & 0.4 & \\
\hline 22 & 25.33 & 67.00 & 479 & 153 & 73 & 705 & 1214 & & 624 & & 0.3 & \\
\hline 23 & 25.00 & 67.00 & 741 & 226 & 143 & 1110 & 565 & 878 & 1361 & 50 & 0.8 & 41 \\
\hline 24 & 24.50 & 67.00 & 540 & 182 & 105 & 827 & 917 & & 666 & & 0.4 & \\
\hline \multicolumn{13}{|c|}{ Transect 3} \\
\hline 33 & 30.00 & 70.01 & 836 & 245 & 151 & 1232 & & & 799 & 57 & 0.6 & \\
\hline 32 & 28.99 & 70.00 & 655 & 640 & 170 & 1465 & 1333 & 1266 & 744 & 43 & 0.3 & 24 \\
\hline 31 & 28.00 & 70.00 & 683 & 359 & 101 & 1143 & 568 & & 830 & & 0.5 & \\
\hline 30 & 27.50 & 70.00 & 843 & 58 & 112 & 1013 & 734 & & 609 & & 0.3 & \\
\hline 29 & 27.03 & 70.09 & 845 & 325 & 156 & 1326 & 534 & 212 & 913 & 54 & 0.5 & 183 \\
\hline 28 & 26.50 & 70.00 & 787 & 311 & 146 & 1244 & 687 & & 898 & & 0.5 & \\
\hline 27 & 26.00 & 70.00 & 599 & 229 & 166 & 994 & 703 & & 774 & 47 & 0.5 & \\
\hline 26 & 25.50 & 70.00 & 771 & 148 & 150 & 1069 & 1199 & & 807 & & 0.4 & \\
\hline 25 & 24.99 & 70.00 & 870 & 222 & 113 & 1205 & 551 & & 827 & 36 & 0.5 & \\
\hline
\end{tabular}



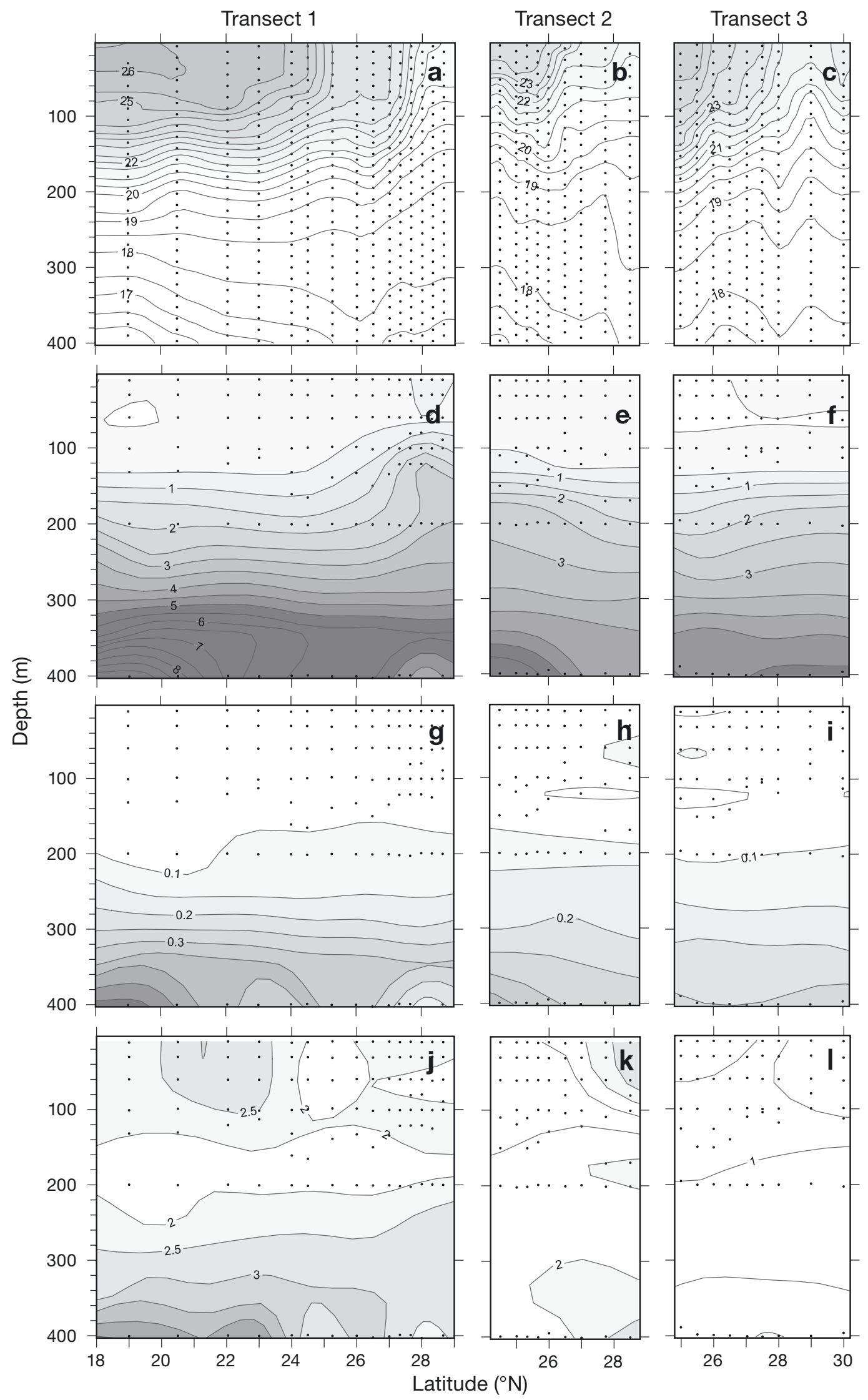

Fig. 2. Vertical distribution of temperature and major nutrients along the 3 transects. $(\mathrm{a}-\mathrm{c})$ Water temperature $\left({ }^{\circ} \mathrm{C}\right)$ and $(\mathrm{d}-\mathrm{l}) \mathrm{nu}-$ trients $\left(\mu \mathrm{mol}^{-1}\right)$ : $(\mathrm{d}-\mathrm{f})$ nitrate, (g-i) phosphate and $(j-1)$ silicate 
$\sim 0.05 \mu \mathrm{mol} \mathrm{l} \mathrm{l}^{-1}$ (Fig. 2g-i) and 1-3 $\mu \mathrm{mol} \mathrm{l^{-1 }}$ (Fig. 2j-l), respectively. Comparison of the 3 major nutrient species in relation to the Redfield ratio suggested nitrogen limitation of the primary production in the upper $150 \mathrm{~m}$ (Fig. 3). Here, both phosphorus and silica were generally present in excess relative to the Redfield ratio, while at 200 to $400 \mathrm{~m}$, nitrogen was slightly in excess relative to phosphorus.

\section{Primary producers: distribution and activity}

Chl a concentrations were low ( 0.1 to $\left.0.2 \mathrm{mg} \mathrm{m}^{-3}\right)$ in the upper $50 \mathrm{~m}$, and a maximum $\left(0.4\right.$ to $0.7 \mathrm{mg} \mathrm{m}^{-3}$ ) was recorded in the upper thermocline at $\sim 100$ to $150 \mathrm{~m}$ depth (Figs. 4a-c \& 5). At $200 \mathrm{~m}$ depth, the chl a concentration was generally $<0.05 \mathrm{mg} \mathrm{m}^{-3}$. The picoplankton biomass generally exceeded that of the larger
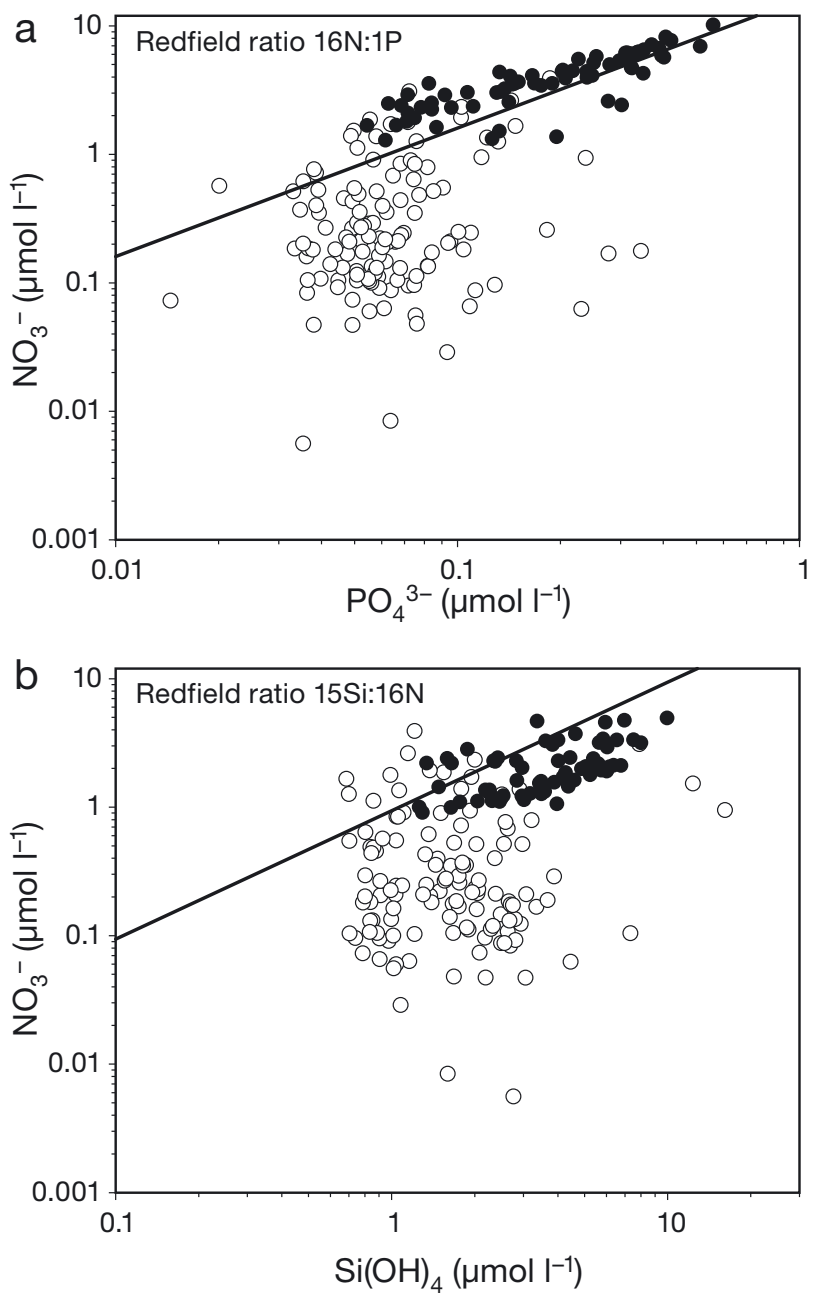

Fig. 3. Relationship between (a) phosphate and nitrate and (b) silica and nitrate at 0 to $150 \mathrm{~m}(\mathrm{O})$ and 200 to $400 \mathrm{~m}$ (ब). Lines indicate Redfield ratios of the nutrients under consideration phytoplankton but with large differences between stations (Table 2). In general, the phytoplankton $>10 \mu \mathrm{m}$ accounted for 5 to $10 \%$ of the total chl $a$ at all stations except for at a single station $\left(26^{\circ} \mathrm{N}\right.$, Transect 2$)$ where it accounted for $19 \%$ (Fig. 5). The biomass of the larger autotrophic community ( $>4 \mu \mathrm{m})$, which varied up to 2to 3 -fold between adjacent stations (Table 2), was dominated by small flagellates (range $0.8 \times 10^{5}$ to $14.0 \times 10^{5}$ cells $\mathrm{l}^{-1}$; Fig. 5). Centric and pennate diatoms $(<20 \mu \mathrm{m})$ were relatively rare (range $0.001 \times 10^{3}$ to $4.3 \times 10^{3}$ cells $\mathrm{l}^{-1}$ ), and only few larger autotrophic thecate dinoflagellates, such as Torodinium sp., Oytoxum sp. and Ceratium sp., were observed. Still at some stations, e.g. within the STCZ at Transect 2, the larger phytoplankton accounted for most of the biomass of primary producers (Table 2).

The abundances of Synechococcus, Prochlorococcus and picoalgae were significantly correlated to the distribution of chl a $\left(\mathrm{r}^{2}=0.09,0.42\right.$ and 0.59 , respectively; $\mathrm{n}=204$ for each). Synechococcus abundance was variable between stations but generally highest in the upper water column with few cells present deeper than $100 \mathrm{~m}$ (Fig. 4j-1). At some stations, Synechococcus abundance was highest at $\sim 100 \mathrm{~m}$ depth. Prochlorococcus was more abundant and showed a deeper distribution with maximal abundance around the chl a maximum at 100 to $150 \mathrm{~m}$ (Fig. 4g-i). Few Prochlorococcus cells were found below $\sim 150 \mathrm{~m}$. Picoalgae were less abundant, generally with highest concentrations occurring at 60 to $150 \mathrm{~m}$ (Fig. 4d-f). Nevertheless, picoalgae explained $59 \%$ of the variation in chl $a_{\text {, }}$ probably as a consequence of their relatively large size (Table 1). In terms of carbon biomass, Prochlorococcus dominated the picophytoplankton at all stations (Table 2), with the average proportions of 6:2:1 for Prochlorococcus:Synechococcus:picoalgae for all sampled stations. Like the larger phytoplankton, the total picoplankton biomass varied up to 2- to 3-fold between adjacent stations (Table 2).

While horizontal distributions of phytoplankton groups (Table 2) were not significantly responsive to the thermal fronts associated with the STCZ, levels of chl a were elevated in these zones when integrating a wider range of the water column ( 0 to $200 \mathrm{~m}$ ) ensuring full coverage of the pycnocline. Increases in such averaged chl a concentrations were evident at the front associated with the southern border of the STCZ at $\sim 25^{\circ} \mathrm{N}$, and particularly areas at the northern border of STCZ at $\sim 28^{\circ} \mathrm{N}$ (Fig. 6) had very high chl a concentrations (Transect 1; Table 2).

Photosynthesis was significantly correlated with chl a $\left(\mathrm{r}^{2}=0.42, \mathrm{n}=45\right)$, nitrate $\left(\mathrm{r}^{2}=0.15, \mathrm{n}=40\right)$, and nitrite $\left(\mathrm{r}^{2}=0.24, \mathrm{n}=40\right)$ but showed large variations between stations (Table 2). Rates of fixation ranged

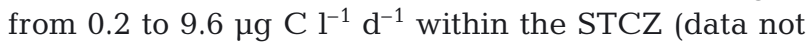



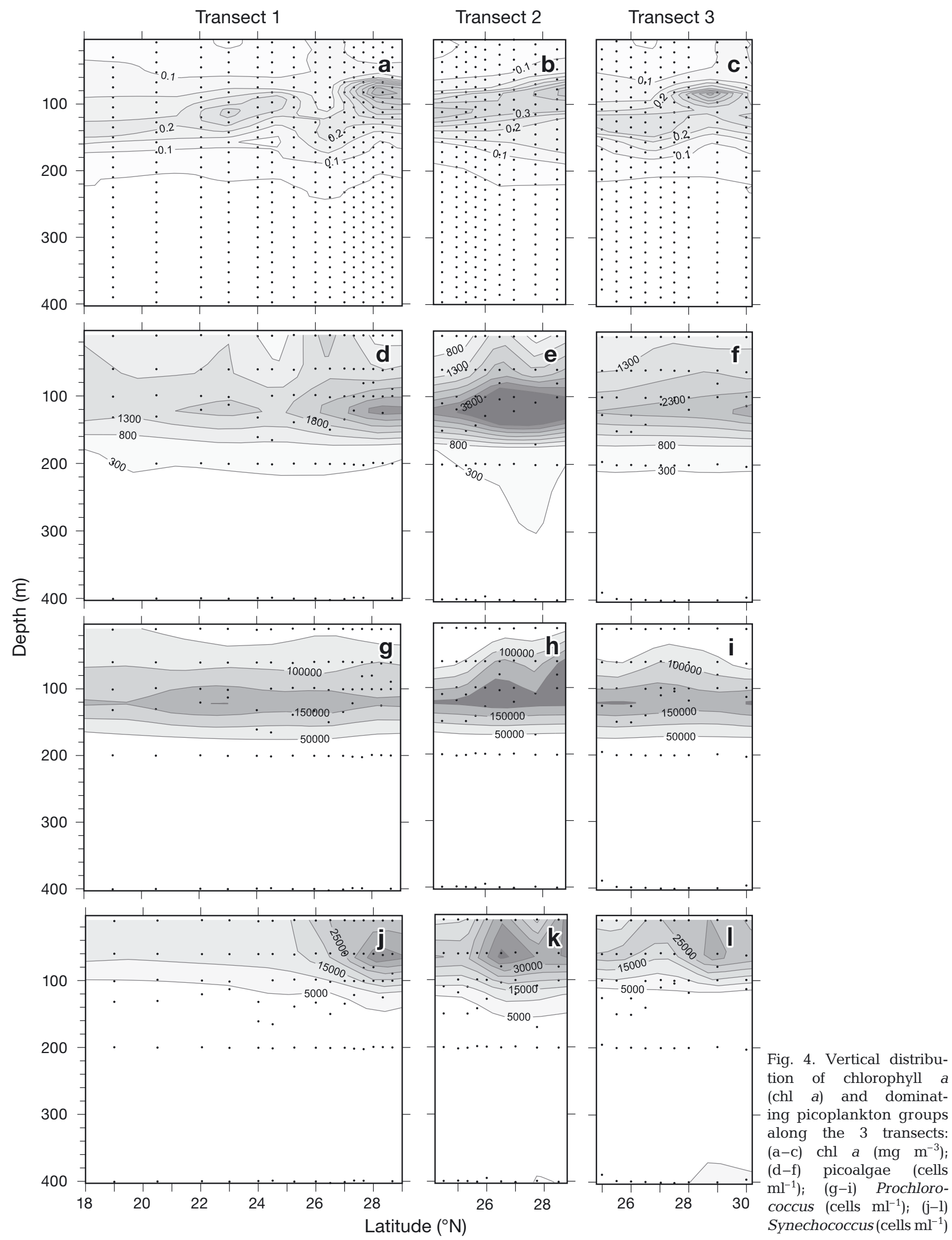

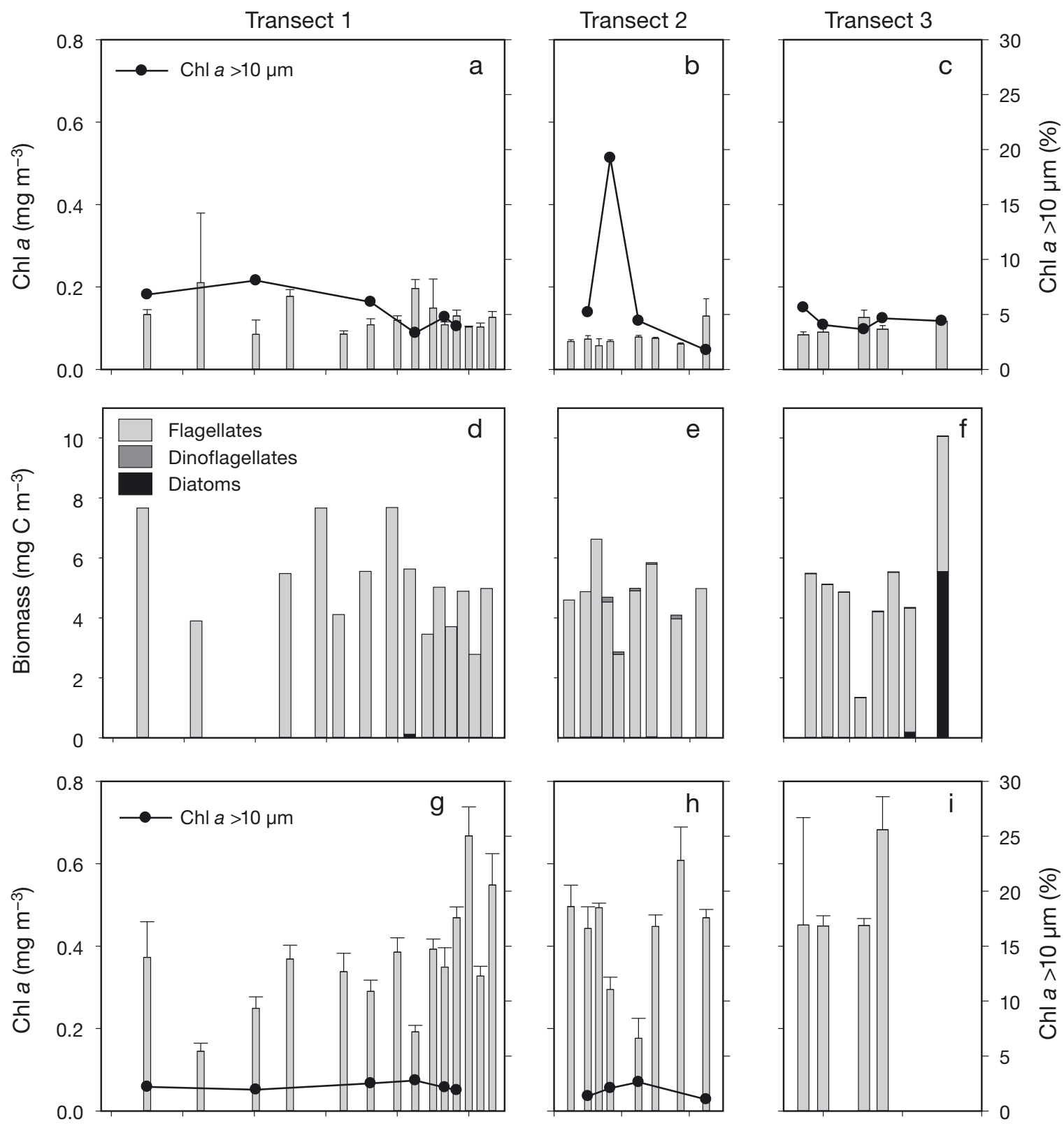

Fig. 5. Surface concentrations of $(\mathrm{a}-\mathrm{c})$ chlorophyll a (chl $a$, $\mathrm{mg} \mathrm{m}^{-3}$ ) and $(\mathrm{d}-\mathrm{f})$ phototrophic protists $>4 \mu \mathrm{m}$ and subsurface layer concentrations of $(\mathrm{g}-\mathrm{i}) \mathrm{chl}$ a and $(\mathrm{j}-\mathrm{l})$ phototrophic protists.
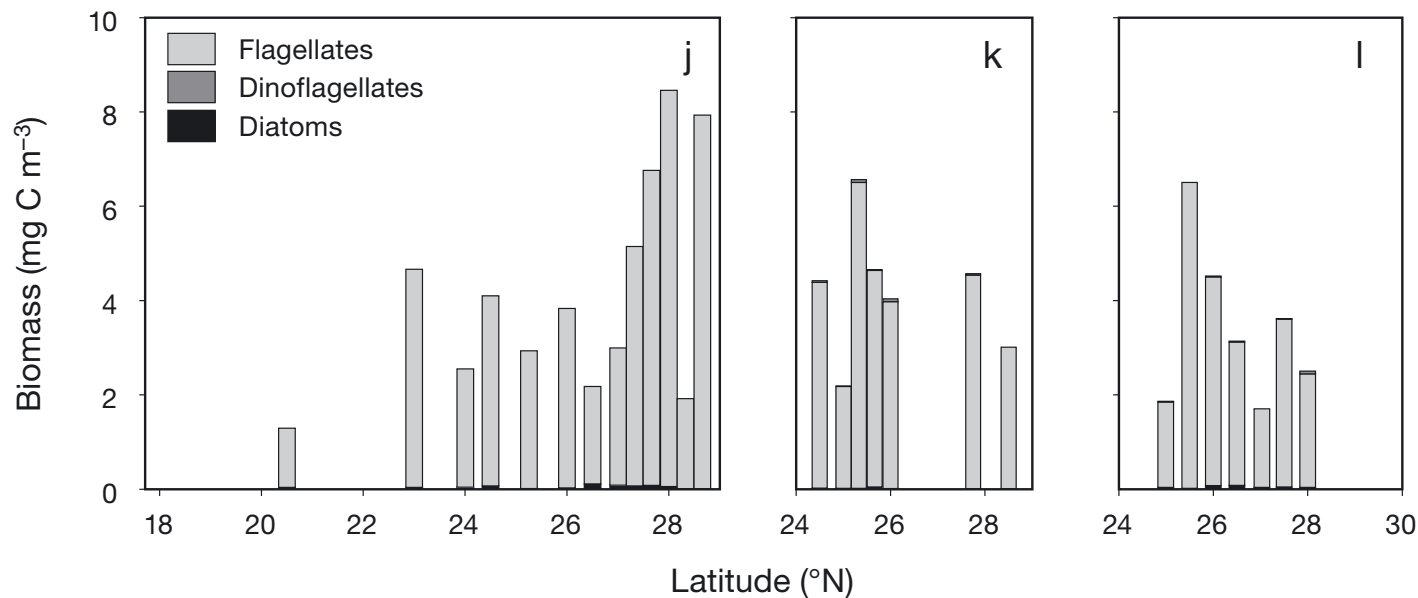
Error bars are SD 


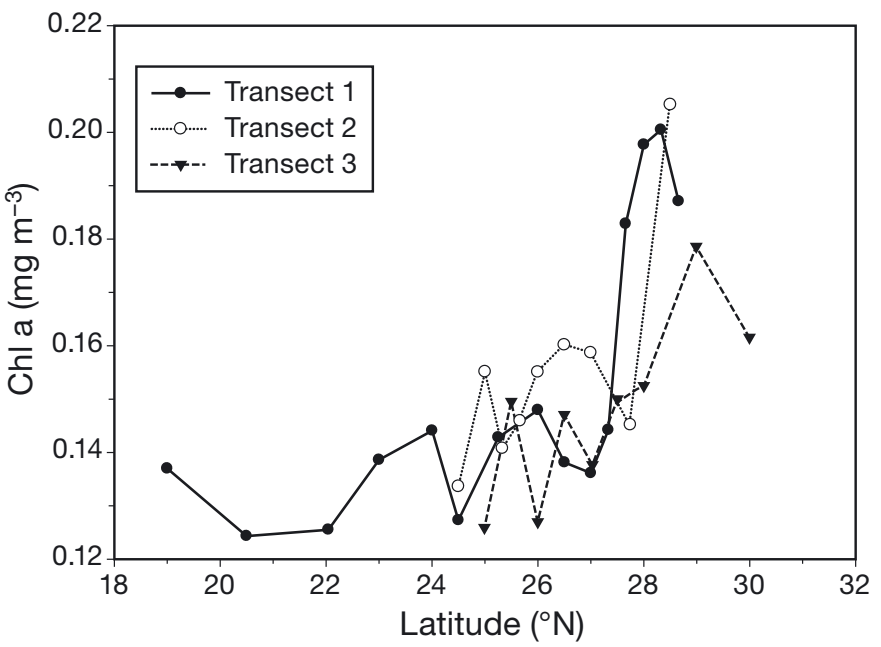

Fig. 6. Average chlorophyll a (chl a) concentrations at 0 to $200 \mathrm{~m}$ depth for individual stations at the 3 transects, calculated from CTD fluorescence profiles using the relationship between fluorescence and measured chl a $\left(\mathrm{r}^{2}=0.86, \mathrm{n}=86\right)$

shown). Despite the depth of the sub-surface chl a peak, the phytoplankton were capable of actively carrying out photosynthesis. Between 10 and almost $90 \%$ of the total water column photosynthesis was estimated to take place in the chl a sub-surface peak at the stations sampled here. As predicted for low light adapted cells, the chl a normalised maximum rate of photosynthesis $\left(\mathrm{P}_{\max }\right)$ was, for most of the stations, lower for the phytoplankton in the sub-surface chl a peak than in the $10 \mathrm{~m}$ samples. However, exceptions were observed in the STCZ where Stns 7 and 22 had a higher chl a-normalised $\mathrm{P}_{\max }$ in the sub-surface peak than at $10 \mathrm{~m}$.

\section{Heterotrophic bacteria: distribution and activity}

Bacterial abundance and production were significantly correlated to $\mathrm{chl}$ a $\left(\mathrm{r}^{2}=0.27, \mathrm{n}=204\right.$ and $\mathrm{r}^{2}=$ $0.58, \mathrm{n}=102$, respectively) and to each other $\left(\mathrm{r}^{2}=0.69\right.$, $\mathrm{n}=105$ ). Bacterial abundance declined with increasing depth and increased significantly with temperature in surface waters $\left(10 \mathrm{~m}, \mathrm{r}^{2}=0.27, \mathrm{n}=33\right)$, as evidenced by elevated abundance in the upper water masses in the warmer southern parts of the transects (Fig. $7 \mathrm{a}-\mathrm{c}$ ). Bacterial production was highest at the southern stations of Transect 1 and at the northernmost stations of

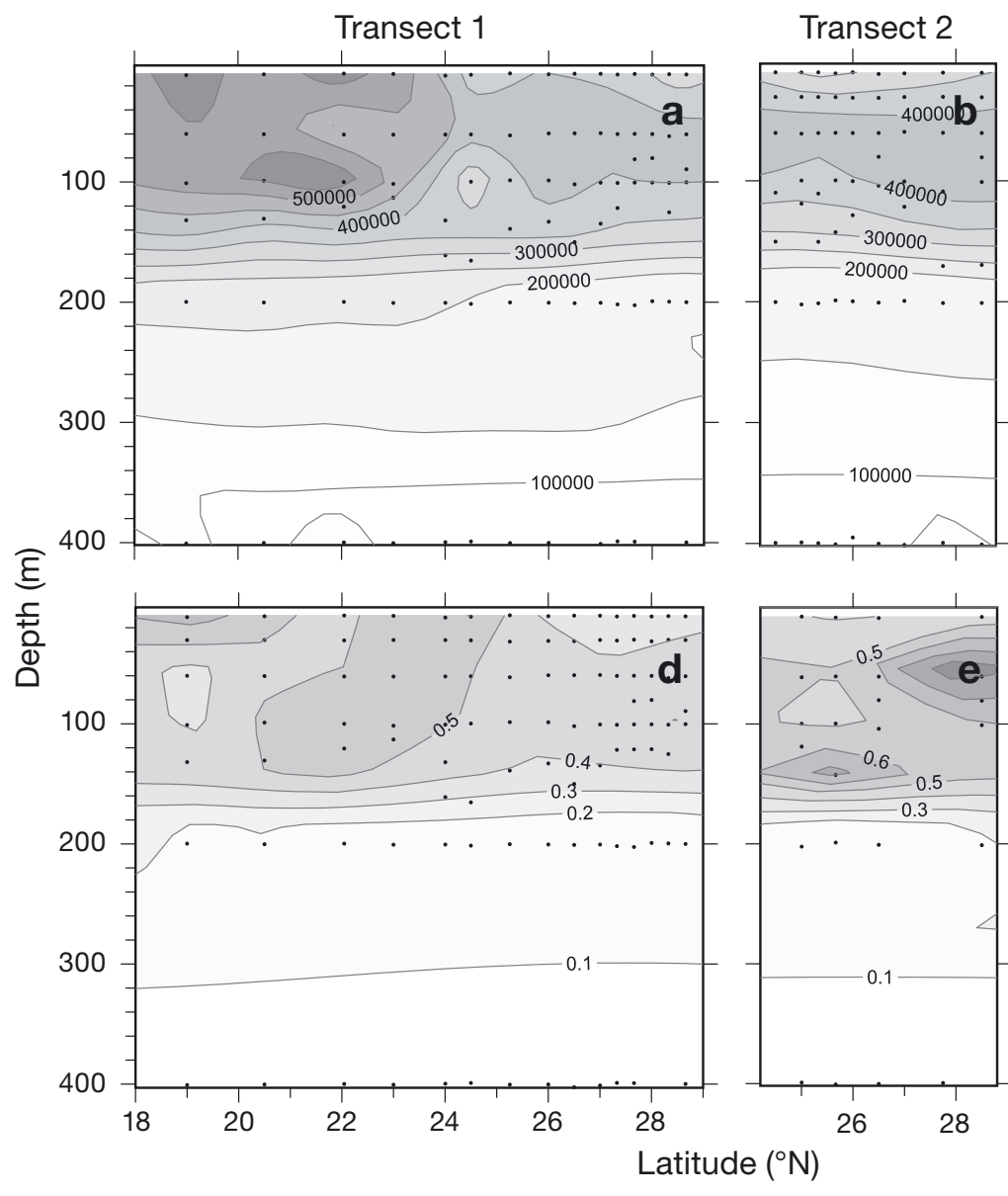

Fig. 7. Vertical distribution of $(\mathrm{a}-\mathrm{c})$ bacterial abundance (cells ml ${ }^{-1}$ ) and $(\mathrm{d}-\mathrm{f})$ production $\left(\mu \mathrm{C} \mathrm{Cl}^{-1} \mathrm{~d}^{-1}\right.$ ) along the 3 transects 
Transects 2 and 3 (Fig. $7 d-f$ ). Within the STCZ, the highest rates of production were generally found at

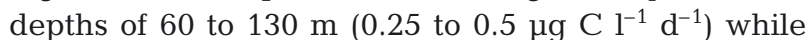
rates decreased to averages of $<0.02 \mu \mathrm{g} \mathrm{C}^{-1} \mathrm{~d}^{-1}$ below $200 \mathrm{~m}$ depth (Fig. 7d-f).

Biomass-specific bacterial growth rate (assuming exponential growth) was, on average, $0.04 \mathrm{~d}^{-1}$ in the photic zone (range 0.002 to $0.08 \mathrm{~d}^{-1}$ ), and correlated with primary production $\left(\mathrm{r}^{2}=0.31, \mathrm{n}=45\right)$, and slightly but significantly correlated with chl a $\left(\mathrm{r}^{2}=0.16, \mathrm{n}=\right.$ 102) and the abundance of Synechoccoccus $\left(r^{2}=0.14\right.$, $\mathrm{n}=105)$ and picoalgae $\left(\mathrm{r}^{2}=0.09, \mathrm{n}=105\right)$.

\section{Integrated biomass and production of primary and secondary producers}

Integrated values of biomass (0 to $400 \mathrm{~m}$ ) as well as ratios between the biomass of primary and secondary producers are shown in Table 2 . The upper water mass ( 0 to $150 \mathrm{~m}$ ) contained most of the biomass and production. Relative to 0 to $400 \mathrm{~m}$, this stratum contained $66 \pm$ $4 \%$ and $92 \pm 5 \%$ of the biomass of bacteria and primary producers, respectively. In addition, $80 \pm 6 \%$ of the bacterial production was located in the upper water mass. The integrated bacterial biomass and production, and phytoplankton biomass within the STCZ did not differ significantly from outside of the STCZ ( $t$-test, 0 to $400 \mathrm{~m}$ depth). Increased integrated bacterial biomass was found at the warm water southern stations on Transect 1 (Stns 1 to 4) while in the STCZ, the bacterial biomass did not vary much between stations $\left(940 \pm 44 \mathrm{mg} \mathrm{C} \mathrm{m}{ }^{-2}, 0\right.$ to $\left.400 \mathrm{~m}\right)$.

\section{DISCUSSION}

The phytoplankton biomass in the Sargasso Sea was generally dominated by picoplankton, and similar to other oligotrophic oceans (Chisholm et al. 1988, Campbell et al. 1997), the cyanobacterium Prochlorococcus dominated in this group. Likewise, our observation of a large standing stock of bacteria in the Sargasso Sea is consistent with the general high importance of bacterioplankton for carbon cycling in warm oligotrophic oceans (Cho \& Azam 1990, Duarte et al. 2001, Hoppe et al. 2002), where net heterotrophic conditions prevail at surface temperatures $>23^{\circ} \mathrm{C}$ (Hoppe et al. 2002, but see Maranon et al. 2007). Overall, the biomasses and growth of bacterio- and phytoplankton were of the same order as in oligotrophic regions of the Mediterranean Sea (Turley et al. 2000) or the northern subtropical Atlantic Ocean (Vázquez-Domínguez et al. 2008), while they were significantly lower than in the North Pacific subtropical gyre (Jones et al. 1996).

\section{Biomass and production of primary producers}

Dominance by picoplankton biomass has been reported from other regions in the Sargasso Sea (Fuhrman et al. 1989, Li et al. 1992, Malone et al. 1993). Likewise, our finding of Prochlorococcus as the most abundant phytoplankton genus is consistent with reports of pronounced Prochlorococcus subsurface blooms in the Sargasso Sea (Olson et al. 1990, Li et al. 1992, Goericke \& Welschmeyer 1993) and the estimate that this genus accounts for $\sim 25 \%$ of the seasonal primary production (Goericke \& Welschmeyer 1993). We located Prochlorococcus deeper in the water column than Synechococcus, a common observation, even more pronounced in summertime in the Sargasso Sea (Olson et al. 1990), which may be attributed to differences in their physiological responses to light (Moore et al. 1995).

The dominance of Prochlorococcus in the picophytoplankton carbon biomass, which occurred in the proportions 6:2:1 for Prochlorococcus:Synechococcus: picoalgae, contrasts with data from a station north of Bermuda, where the corresponding proportions were 2:1:4 in fall 1988 (Li et al. 1992). Similar proportions were found at the BATS stations (DuRand et al. 2001). Seasonal variation may be an explanation for the different results, given that Synechococcus reaches highest yearly concentrations specifically at the time of our sampling in spring (DuRand et al. 2001). Other potential explanations include the use of different carbon conversion factors and the uncertainties associated with size estimates of picoplankton using flow cytometry and cultivated strains; however, a plausible explanation could also be a generally higher abundance of picoalgae in the more nutrient-rich waters north of the STCZ. Consistent with this idea, we found picoalgae to be $\sim 10$-fold more abundant at a station on the same latitude as Bermuda relative to stations within the STCZ (data not shown).

The primary production was highly variable between stations ranging from 118 to $1266 \mathrm{C} \mathrm{m}^{-2} \mathrm{~d}^{-1}$. Malone et al. (1993) measured a mean rate of $333 \mathrm{mg} \mathrm{C}$ $\mathrm{m}^{-2} \mathrm{~d}^{-1}$ for the euphotic zone at a station near Bermuda in spring 1990. Interestingly, these authors found that picoplankton generally accounted for most production, but the chl a variance was highest for the microplankton due to a patchy distribution. For instance, diatoms are usually rare but occasionally important near or north of Bermuda (Malone et al. 1993, Nelson \& Brzezinski 1997, Schnetzer \& Steinberg 2002) as a consequence of $18^{\circ} \mathrm{C}$ water ventilation (Siegel et al. 1990). Consistent with these studies, the fraction of chl $a$ $>10 \mu \mathrm{m}$ was generally only 5 to $10 \%$ of total chl $a$, and diatoms were only found at very low concentrations, except for at the northernmost station on Transect 3 
(Fig. 5). Still, it should be noted that the biomass of larger-sized phytoplankton exceeded that of picoplankton at a few stations (Table 2). Along with the large variability in primary production between stations, the rather patchy distribution of larger-sized phytoplankton suggests a heterogeneous pattern in carbon dynamics in the southern Sargasso Sea.

\section{Bacterial biomass and production}

Bacterial biomass was about half of the phytoplankton biomass (Table 2). High bacterial biomass has previously been estimated in Sargasso Sea samples (e.g. Fuhrman et al. 1989, Li et al. 1992). Bacterial biomass specific growth rate was linked with primary production and chl $a$, probably as a consequence of the production of labile dissolved organic carbon (DOC) through extracellular release from phytoplankton (Mague et al. 1980) and zooplankton sloppy feeding (Lampert 1978). Indeed, the close linkage to phytoplankton biomass and productivity, the availability of phosphate (Fig. 3a), and the absence of correlation between bacterial production and inorganic nitrogen in the photic zone, indicate that bacterial production was limited by labile DOC, as has been suggested earlier (Carlson \& Ducklow 1996).

In order to estimate the proportion of carbon entering the system allocated to bacterial biomass and respiration, we compared the bacterial carbon demand with the primary production (Table 2). The bacterial carbon demand corresponded to 24 to $394 \%$ of the primary production in the euphotic zone. This suggests the presence of carbon sources for bacterial growth other than phytoplankton biomass and new production. One possible source is semi-labile DOC that is slowly oxidised by bacteria (Carlson et al. 1996), but processes causing internal recycling of carbon, such as viral lysis of bacterial cells (e.g. Middelboe \& Lyck 2002), may also help sustain the seemingly high bacterial carbon demand relative to phytoplankton biomass and productivity. Nevertheless, it should be noted that calculations of bacterial carbon demand rely on conversion factors obtained from other regions of the Sargasso Sea (Carlson et al. 1996, Carlson \& Ducklow 1996). As these may not be strictly correct, the estimated carbon demand should be treated with caution.

\section{Characteristics of the STCZ}

Increased plankton biomass and/or productivity are sometimes associated with ocean fronts (Heilmann et al. 1994, Ashjian et al. 2005, Delizo et al. 2007). We therefore hypothesised that biomass and productivity of the lower trophic levels would be elevated in association with the distinct thermal fronts of the STCZ. Indeed, elevated levels of chl a were associated with the thermal fronts bordering the STCZ. While this was not particularly evident from discrete measurement of chl $a$ in surface or sub-surface samples (Fig. 5), more clear patterns were observed when depicting chl a concentrations averaged from the water column (Fig. 6). Nevertheless, significantly elevated levels of primary production or biomass of specific phytoplankton groups or of bacterioplankton were not observed within the STCZ (Table 2). The pronounced variability between stations along transects combined with the limited number of sampled stations may have prevented detection of minor differences between biomass and activity levels associated with the STCZ relative to outside of the STCZ. However, other explanations are also plausible. These are discussed below.

Primary production varied almost 8-fold between stations within the STCZ. While this may reflect actual geographic variation, it could alternatively be due to temporal intermittency. For instance, local primary production may show several-fold day-to-day variation where transient events generate a disproportionately large proportion of yearly primary production (Malone et al. 1993). Interestingly, the photosynthetic characteristics of phytoplankton in the sub-surface peak, at least at some of the stations sampled in the STCZ, differed from those of phytoplankton in sub-surface peaks in the rest of the study area in that the chl a-normalised maximum rate of photosynthesis was higher in the sub-surface peak than at $10 \mathrm{~m}$. This may indicate mixing processes injecting nutrients to the sub-surface peak in this region.

One possible explanation for the lack of elevated biomasses of specific phytoplankton groups or bacterioplankton within the STCZ could be top-down control from the higher trophic levels. Indeed, dilution experiments have demonstrated substantial grazing mortality for Synechococcus and Prochlorococcus in the Sargasso Sea (Worden \& Binder 2003). The STCZ, especially the eastern part, exhibited the highest concentrations of metazooplankton observed in the study (Andersen et al. 2011), despite the fact that neither levels of phytoplankton biomass and production nor the proportion of chl $a$ in the $>10 \mu \mathrm{m}$ fractions were significantly elevated here (Table 2, Fig. 5). Hence, no causal relationship between zooplankton and largersized phytoplankton was observed. However, links between trophic levels in oligotrophic waters are complex. For instance, a coupling between metazooplankton and larger phytoplankton may be blurred by the presence of protozoans (ciliates and dinoflagellates) making the picoplanktonic primary production available to higher trophic levels in the Sargasso Sea 
(Andersen et al. 2011). Moreover, picoplankton-based detritus may be efficiently grazed by mesozooplankton (Richardson et al. 2004) and mediate an efficient carbon export to higher trophic levels (Richardson \& Jackson 2007). Further, larvaceans, which can provide an efficient energy transfer from picoplankton to tertiary consumers through direct feeding on picoplankton (Deibel \& Lee 1992), were highly connected to the STCZ (Andersen et al. 2011).

As has been observed for the subtropical convergence east of New Zealand (Delizo et al. 2007), it is likely that the complex oceanography of the southern Sargasso Sea generates not only high spatial variability, as observed here, but also high temporal variability in biological processes. Since growth represents a shortterm process, whereas biomass represents the cumulative effects of various growth and loss processes over a variety of time scales (Delizo et al. 2007), elevated levels of plankton biomass and production can be hard to capture due to sampling distances and temporal intermittency of both productivity and loss processes. For instance, at a front in the transition zone between the North Sea and the Skagerrak/Kattegat, consistent elevated levels of primary production could not be demonstrated even though phytoplankton biomass was elevated (Heilmann et al. 1994). In our study, the observed between-station variability in lower-level plankton communities probably complicated detection of potential elevated carbon cycling within the STCZ relative to the surrounding water masses. This may explain why significantly elevated levels of primary production or biomass of specific phytoplankton groups in this zone could not be demonstrated. Nevertheless, distinct increases in chl a were associated with the zone and especially with the thermal fronts bordering the STCZ.

Acknowledgements. We thank B. Søborg and W. Martinsen for excellent logistic and technical assistance in association with the expedition. The captain of HMDS 'Vædderen', L. Hansen, and his crew are thanked for excellent assistance with sampling. We thank the anonymous reviewers for constructive comments improving an earlier version of the manuscript. The project was supported by grants from Knud Højgaards Fond, the Danish Natural Sciences Research Council, Nordea Fond, Villum Kann Rasmussen Fond, Elisabeth and Knud Petersens Fond, Carlsberg Foundation and Dansk Expeditions Fond. The present work was carried out as part of the 'Galathea 3' expedition under the auspices of Dansk Expeditions Fond. This is Galathea 3 contribution no. P75.

\section{LITERATURE CITED}

Andersen NG, Nielsen TG, Jakobsen HH, Munk P, Riemann L (2011) Distribution and production of plankton communities in the subtropical convergence zone of the Sargasso Sea. II. Protozooplankton and copepods. Mar Ecol Prog Ser 426:71-86
Ashjian CJ, Davis CS, Gallager SM, Alatalo P (2005) Characterization of the zooplankton community, size composition, and distribution in relation to hydrography in the Japan/East Sea. Deep-Sea Res II 52:1363-1392

Böttger R (1982) Studies on the small invertebrate plankton of the Sargasso Sea. Helgol Wiss Meersunters 35:369-383

> Campbell L, Liu H, Nolla HA, Vaulot D (1997) Annual variability of phytoplankton and bacteria in the subtropical North Pacific Ocean at Station ALOHA during the 1991-1994 ENSO event. Deep-Sea Res I 44:167-192

> Carlson CA, Ducklow HW (1996) Growth of bacterioplankton and consumption of dissolved organic carbon in the Sargasso Sea. Aquat Microb Ecol 10:69-85

Carlson CA, Ducklow HW, Michaels AF (1994) Annual flux of dissolved organic carbon from the euphotic zone in the northwestern Sargasso Sea. Nature 371:405-408

Carlson CA, Ducklow HW, Sleeter TD (1996) Stocks and dynamics of bacterioplankton in the northwestern Sargasso Sea. Deep-Sea Res II 43:491-515

Chisholm SW, Olson RJ, Zettler ER, Goericke R, Waterbury JB, Welschmeyer NA (1988) A novel free-living prochlorophyte abundant in the oceanic euphotic zone. Nature 334: 340-343

Cho BC, Azam F (1990) Biogeochemical significance of bacterial biomass in the ocean's euphotic zone. Mar Ecol Prog Ser 63:253-259

$>$ Deibel D, Lee SH (1992) Retention efficiency of sub-micrometer particles by the pharyngeal filter of the pelagic tunicate Oikopleura vanhoeffeni. Mar Ecol Prog Ser 81:25-30

$>$ Delizo L, Smith WO, Hall J (2007) Taxonomic composition and growth rates of phytoplankton assemblages at the Subtropical Convergence east of New Zealand. J Plankton Res 29:655-670

> Duarte CM, Agusti S, Aristegui J, González N, Anadón R (2001) Evidence for a heterotrophic subtropical northeast Atlantic. Limnol Oceanogr 46:425-428

Ducklow HW (2000) Bacterial production and biomass in the oceans. In: Kirchman DL (ed) Microbial ecology of the oceans. Wiley-Liss, New York, NY, p 85-120

DuRand MD, Olson RJ, Chisholm SW (2001) Phytoplankton population dynamics at the Bermuda Atlantic Timeseries station in the Sargasso Sea. Deep-Sea Res II 48: 1983-2003

Eppley RW, Reid FM, Strickland JDH (1970) Estimates of phytoplankton crop size, growth rate and primary production off La Jolla, CA in the period April through September 1967. Bull Scripps Inst Oceanogr 17:33-42

$>$ Fuhrman JA, Azam F (1982) Thymidine incorporation as a measure of heterotrophic bacterioplankton production in marine surface waters: evaluation and field results. Mar Biol 66:109-120

Fuhrman JA, Sleeter TD, Carlson CA, Proctor LM (1989) Dominance of bacterial biomass in the Sargasso Sea and its ecological implications. Mar Ecol Prog Ser 57:207-217

- Gasol JM, del Giorgio PA, Duarte CM (1997) Biomass distribution in marine planktonic communities. Limnol Oceanogr 42:1353-1363

Goericke R, Welschmeyer NA (1993) The marine prochlorophyte Prochlorococcus contributes significantly to phytoplankton biomass and primary production in the Sargasso Sea. Deep-Sea Res I 40:2283-2294

Grasshoff K, Ehrhardt M, Kremling K (1983) Methods of seawater analysis. Verlag Chemie, Weinheim

> Halliwell GR Jr, Peng G, Olson DB (1994) Stability of the Sargasso Sea Subtropical Frontal Zone. J Phys Oceanogr 24: $1166-1183$

Heilmann JP, Richardson K, Ærtebjerg G (1994) Annual dis- 
tribution and activity of phytoplankton in the Skagerak/ Kattegat frontal region. Mar Ecol Prog Ser 112:213-223

Hoppe HG, Gocke K, Koppe R, Begler C (2002) Bacterial growth and primary production along a north-south transect of the Atlantic Ocean. Nature 416:168-171

Høyer JL, She J (2007) Optimal interpolation of sea surface temperature for the North Sea and the Baltic Sea. J Mar Syst 65:176-189

Jespersen AM, Christoffersen K (1987) Measurements of chlorophyll-a from phytoplankton using ethanol as extraction solvent. Arch Hydrobiol 109:445-454

> Jones DR, Karl DM, Laws EA (1996) Growth rates and production of heterotrophic bacteria and phytoplankton in the North Pacific subtropical gyre. Deep-Sea Res I 43: $1567-1580$

> Kirchman D, K'nees E, Hodson R (1985) Leucine incorporation and its potential as a measure of protein synthesis by bacteria in natural aquatic systems. Appl Environ Microbiol 49:599-607

Lampert W (1978) Release of dissolved organic carbon by grazing zooplankton. Limnol Oceanogr 23:831-834

Li WKW, Dickie PM, Irwin BD, Wood AM (1992) Biomass of bacteria, cyanobacteria, prochlorophytes and photosynthetic eukaryotes in the Sargasso Sea. Deep-Sea Res 39: 501-519

Lohrenz ES, Knauer GA, Asper VL, Tuel M, Michaels AF, Knap AH (1992) Seasonal variability in primary production and particle flux in the northwestern Sargasso Sea: U.S. JGOFS Bermuda Atlantic Time-series Study. DeepSea Res 39:1373-1391

Mague TH, Friberg E, Hughes DJ, Morris I (1980) Extracellular release of carbon by marine phytoplankton; a physiological approach. Limnol Oceanogr 25:262-279

Malone TC, Pike SE, Conley DJ (1993) Transient variations in phytoplankton productivity at the JGOFS Bermuda time series station. Deep-Sea Res I 40:903-924

- Maranon E, Pérez V, Fernández E, Anadón R and others (2007) Planktonic carbon budget in the eastern subtropical North Atlantic. Aquat Microb Ecol 48:261-275

Marie D, Partensky F, Jacquet S, Vaulot D (1997) Enumeration and cell cycle analysis of natural populations of marine picoplankton by flow cytometry using the nucleic acid stain SYBR Green I. Appl Environ Microbiol 63: 186-193

Menden-Deuer S, Lessard EJ (2000) Carbon to volume relationships for dinoflagellates, diatoms, and other protist plankton. Limnol Oceanogr 45:569-579

Middelboe M, Lyck PG (2002) Regeneration of dissolved organic matter by viral lysis in marine microbial communities. Aquat Microb Ecol 27:187-194

Moore LR, Goericke R, Chisholm SW (1995) Comparative physiology of Synechococcus and Prochlorococcus: influence of light and temperature on growth, pigments, fluorescence and absorptive properties. Mar Ecol Prog Ser 116:259-275

Munk P, Maes GE, Hansen MM, Nielsen TG and others

Editorial responsibility: Edward Durbin,

Narragansett, Rhode Island, USA
(2010) Oceanic fronts in the Sargasso Sea control the early life and drift of Atlantic eels. Proc R Soc B 277:3593-3599

Nelson DM, Brzezinski MA (1997) Diatom growth and productivity in an oligotrophic midocean gyre: a 3-yr record from the Sargasso Sea near Bermuda. Limnol Oceanogr 42:473-486

> Olson RJ, Chisholm SW, Zettler ER, Altabet MA, Dusenberry JA (1990) Spatial and temporal distributions of prochlorophyte picoplankton in the North Atlantic Ocean. DeepSea Res 37:1033-1051

Platt T, Gallegos CL, Harrison WG (1980) Photoinhibition of photosynthesis in natural assemblages of marine phytoplankton. J Mar Res 38:687-701

> Richardson TL, Jackson GA (2007) Small phytoplankton and carbon export from the surface ocean. Science 315 : 838-840

Richardson TL, Jackson GA, Ducklow HW, Roman MR (2004) Carbon fluxes through food webs of the eastern equatorial Pacific: an inverse approach. Deep-Sea Res I 51: $1245-1274$

Roman MR, Dam HG, Gauzens AL, Napp JM (1993) Zooplankton biomass and grazing at the JGOFS Sargasso Sea time series stations. Deep-Sea Res I 40:883-901

Schnetzer A, Steinberg DK (2002) Natural diets of vertically migrating zooplankton in the Sargasso Sea. Mar Biol 141: 89-99

> Siegel DA, Iturriaga R, Bidigare RR, Smith RC and others (1990) Meridional variations of the springtime phytoplankton community in the Sargasso Sea. J Mar Res 48: 379-412

Steeman Nielsen E (1952) The use of radio-active carbon $\left(\mathrm{C}^{14}\right)$ for measuring organic production in the sea. J Cons Perm Int Explor Mer 18:117-140

Steinberg DK, Carlson CA, Bates NR, Johnson RJ, Michaels AF, Knap AH (2001) Overview of the US JGOFS Bermuda Atlantic Time-series Study (BATS): a decade-scale look at ocean biology and biogeochemistry. Deep-Sea Res II 48: 1405-1447

> Turley CM, Bianchi M, Christaki U, Conan P and others (2000) Relationship between primary producers and bacteria in an oligotrophic sea - the Mediterranean and biogeochemical implications. Mar Ecol Prog Ser 193:11-18

> Vázquez-Domínguez E, Duarte CM, Agustí S, Jürgens K, Vaqué D, Gasol JM (2008) Microbial plankton abundance and heterotrophic activity across the central Atlantic Ocean. Prog Oceanogr 79:83-94

- Voorhis AD, Hershey JB (1964) Oceanic thermal fronts in the Sargasso Sea. J Geophys Res 69:3809-3814

Wegner G (1982) Main hydrographic features of the Sargasso Sea in spring 1979. Helgol Wiss Meersunters 35: $385-400$

- Worden AZ, Binder BJ (2003) Application of dilution experiments for measuring growth and mortality rates among Prochlorococcus and Synechococcus populations in oligotrophic environments. Aquat Microb Ecol 30: 159-174

Submitted: June 3, 2010; Accepted: December 15, 2010 Proofs received from author(s): March 7, 2011 